\title{
Mass Mentality, Culture Industry, Fascism
}

\section{Saladdin Said Ahmed}

S ome fashionable leftist movements and populist intellectuals habitually blame the sources of information for public ignorance about the miserable state of the world. It could be argued, however, that the masses are ignorant because they prefer ignorance. A mass individual is politically apathetic and intellectually lazy. As a result, even when huge amounts of information are available, which is the case in this epoch, the masses insist on choosing ignorance. It is true that there is not enough information about what has happened in a place such as Darfur, but the masses choose not to access even the amount of information that is available. The great majority of people in China, Iran, and America, despite the fact that they have varying amounts of access to various types of "knowledge," still tend to be misinformed. It seems that a mass individual is curious only about what directly affects his/her own personal life. I will explore the connection between mass mentality and the culture industry in order to capture the essential role of the former in the latter. I will also argue that a mass individual is the source of fascism although fascism as a phenomenon needs a mass culture in which to flourish.

\section{Culture Industry and Mass Mentality}

According to Adorno, the "industry" in the "culture industry" should not be taken literally. The term refers more to the standardization and techniques of distribution than to the process of production and actual creation. ${ }^{1}$ However, he seems to focus more on the manipulative character of culture industry as a system run by dominant groups. In fact, he says, "the culture industry intentionally integrates its consumers from above." 2 He rejects the idea that masses are the only source of mass culture and that is why the term "culture industry" is so crucial for him. ${ }^{3}$ This common interpretation of culture industry has been taken too far. This interpretation of the culture industry has become more like a kind of conspiracy theory that claims the masses as victims of a minority that dominates them from above through

\footnotetext{
1 Theodor W. Adorno, The Culture Industry: Selected Essays on Mass Culture (London: Routledge, 2001), 96.

2 Ibid., 98.

${ }^{3}$ Ibid., 98.
} 


\section{MASS MENTALITY}

controlling the media and monopolizing all other canals of mass culture and ideology. Adorno himself is aware of this possible misunderstanding. For example, he and Horkheimer state, "the mentality of the public, which allegedly and actually favors the system of culture industry, is a part of the system not an excuse for it." 4 Culture is an embodiment of mentality in its collective form. It cannot simply be a product created by elites. Dominant groups can modify elements of popular culture, but they cannot determine its boundaries and content because the popular mentality has its own filters and internal processes. Mass media can observe the conditions of what becomes a part of popular culture and accordingly put their own agenda to work within the culture industry, but they cannot alone be held responsible for the "production" of the culture. Mass media can make a philosopher relatively popular, but they cannot make philosophy a popular field. The mass mentality is attracted to certain things and distracted by others, and the culture industry functions accordingly. In a consumer society, happiness is sought in commodities. There is always at least one more thing claiming to bring a consumer happiness, and since, of course, this is a psychological obsession, the chain of alienations and frustrations increases continually, which makes the consumer more submissive to the addictive system of consumption. Commercials have one major message for their obsessed subjects: this new item in particular is the key to your lost happiness; this item is unlike anything we have offered you before. Commercialism and commodity fetishism turn the mass individual into an apolitical individual who serves the system of advanced capitalism even in his or her "free time".

In "Culture Industry Reconsidered," Adorno writes, "the masses are not the measure but the ideology of the culture industry, even though the culture industry itself could scarcely exist without adapting to the masses." ${ }^{5} \mathrm{He}$ also says, "the entire practice of the culture industry transfers the profit motive naked onto cultural forms." 6 Culture industry makes every cultural item just another commodity that subscribes to the principles of the capitalist market. The masses play a crucial role in the system of culture industry though that role is passive. Masses are the target and medium of commercialism. They sustain the system of culture industry with their passive apolitical role just as they sustain the bigger capitalist system of domination. Masses attract more masses and are used for that purpose in the capitalist society that is shaped by the dynamics of the market. Mass culture is market-based, fetishism is its driving power, and it is a major venue for commercials that persuade the mass individual to become a submissive consumer of endless commodities. Culture industry does not have a specific agenda to stupidize the mass individual; rather, it invests in the mass individual's fetishistic attitude towards commodities.

4 Max Horkheimer and Theodor Adorno, Dialectic of Enligbtenment: Philosophical

Fragments, trans. by Edmund Jephcott (Stanford: Stanford University Press, 2002), 96.

${ }^{5}$ Adorno, Culture Industry, 99.

${ }^{6}$ Ibid., 98 . 
Most corporations have one simple ideology and that is the basic ideology of the capitalist system itself: profit. Some fundamental principles of capitalism have not changed since Marx's time and one of them is that the source of power in a capitalist system is accumulation of capital that depends on the principle of maximizing profit. The most essential principle of any nonnon-profit corporation in the "free market" system is profit, otherwise it would simply bankrupt within the bigger capitalist system. That means corporations that control the media produce what is profitable: what is popular. Of course, the wants, desires, and values are also created or fueled within the system of the industry, but again, not according to a mono-dimensional power relation, but according to hegemonic process that involves both persuasion and consent.

However, it would also be foolish to dismiss the role of domination in the culture industry. Adorno writes, "the customer is not king, as the culture industry would have us believe, not its subject but its object." 7 The theory of culture industry came about in the first place to emphasize the fact that there is a process of domination within the process of formation of culture. However "domination" should not be reduced to a direct political notion of domination, as I will explain later. Both simple interpretations, that which sees the masses as the source of mass culture and that which sees the dominant groups as the source of mass culture, are equally inaccurate. The relation between the mass mentality and the process of culture industry is a dialectical one. The culture industry is not a simple relation between manufacturers and consumers or between the dominant and the dominated. Rather, there is a two-fold relationship between culture as a monopoly and popular mentality within the system of the culture industry. In Adorno's words, "the culture industry misuses its concern for the masses in order to duplicate, reinforce and strengthen their mentality, which it presumes is given and unchangeable." 8 Thus, culture circulates between masses and the dominant forces. It is more accurate to say that the mass mentality and dominant groups are the two folds of the culture industry. This discussion will become clearer when I look at popular culture later on in this essay.

The question of domination, as Foucault would say, should be analyzed in its socio-historical context rather than in terms of the simple political domination of some class or group over another. Truth or knowledge itself is a matter of industry. We learn from Foucault's genealogy that the question of domination cannot be interpreted in isolation from the question of knowledge and neither of them can be interpreted in isolation of the history of the subject. However, once we step into the realm of the masses, as opposed to individual subjects, the chain of the concepts will shift. With masses, "power" takes the form of fascism and "knowledge" takes the form of culture.

\footnotetext{
${ }^{7}$ Ibid., 99

${ }^{8}$ Ibid.
} 


\section{MASS MENTALITY}

If Foucault's arguments regarding, "power and knowledge directly imply each other," 9 are sound, then fascism and culture also always imply each other.

There is more than one way to show this dialectical relation between culture and fascism from the point of view of critical theory. Horkheimer and Adorno assert the Freudian hypothesis that explains material production in terms of the fear from the outside. In this sense, "terror and civilization are inseparable." 10 A human being develops his or her individual defense system in response to the external resentence represented by every power figure. The collective outcome of this socio-psychological fire is what bakes culture over the course of history. In Horkheimer and Adorno's words, "Culture has evolved under the shadow of the executioner." 11 They continue, "One cannot abolish terror and retain civilization. Even to relax the former means the beginning of disintegration." 12 Does this mean there is a socio-historical consistency behind fascism? Yes, and this is what makes fascism perpetually present, which means the challenge is very real. The authors of The Authoritarian Personality declare that their main hypostasis is, "that the political, economic, and social convictions of an individual often form a broad and coherent pattern, as if bound together by a "mentality" or "spirit", and that this pattern is an expression of deeplying trends in his personality." 13 Fascism is not the product of an oppressive agenda put forward by a certain dominant group as pseudo-intellectuals often imply; rather, it is rooted in mass culture. Horkheimer and Adorno state, "according to the clever people, fascism was impossible in the West. Clever people have always made things easy for barbarians, because they are so stupid." 14 Especially in the contemporary intellectual climate of the United Sates and Canada, and to some extent in Europe, where political correctness highlights what people utter in public rather than their mentality, fascism has found its masks, and hence it is not addressed critically because it is assumed not to exist as a popular force. The intelligentsia, too idle to be concerned about anything that is not boldly uttered, has provided a perfect environment over the last few decades for fascism to creep into and fester within the sectors of mass culture, unnoticed. Unlike fascism in the 1920s and 1930s, today's fascism derives its power from its invisibility, which makes it less detectable, especially in the climate of political correctness.

Meanwhile, Deleuze and Guattari state, "what makes fascism dangerous is its molecular or micropolitical power, for it is a mass movement: a cancerous body rather than a totalitarian organism."15 Pseudo-intellectuals

${ }^{9}$ Michel Foucault, "The Body of Condemned," in Foucault Reader, ed. Paul Rabinow (New York: Pantheon Books, 1984), 174.

${ }^{10}$ Horkheimer and Adorno, Dialectic of Enlightenment, 179-180.

${ }^{11}$ Ibid., 180.

12 Ibid.

13 Theodor W. Adorno et al., The Authoritarian Personality ( New York: Harper \& Row Publications, 1950), 1.

${ }^{14}$ Ibid., 173

15 Gilles Deleuze and Felix Guattari, A Thousand Plateaus; Capitalism and Schirophrenia, trans. by Brian Massumi (Minneapolis: University of Minnesota Press, 1987), 215. 
oversimplify everything. As a result, they always choose an easy target such as a certain political administration, and major media corporations. That way it is easy for the educated middle-class person to take a "political" stance without thinking critically about the state of affairs. The evil and the good are made too obvious to leave any need for real critical thinking. The worst thing in this political stupidization is that fascism grows in almost everyone unnoticed. Recognizing fascism requires individual skills of criticism, which is the last thing to be present in a mass-production society in which even political leftism is produced for mass usage.

The proliferation and internalization of fascism take place through the propagation and internalization of ideologies that capitalize a locallyconstructed collective identity (culture) according to which the mere existence of "the other" represents a normative threat to the fragile situation of "our purity." The germs of fascism are transformed from the fascist communitarian foci into the "individual" mentality of the subjects by the prejudices that are built into the structures of the dominant ideology which is reflected in the main stream media. The potential fascists are the people whose lack of critical individual identity pushes them to search for an alternative passionate collective identity that can invite them into the festive spirit of one extended brotherhood and sisterhood. In this sense the phenomenon of fascism is an existential crisis of individualism. For fascists, culture is exactly what "[gives] meaning to a world which makes them meaningless." 16 For the person whose identity is determined almost entirely by his or her collective background, every other individual is also nothing but a representative of another collective body. This mentality is sickly reductionist: it reduces all humans into a few types, whether races, faiths, nationalities, regions, or cultures. Eventually, in the fascist mentality, the world would be reduced to "they" and "us." For the fascist the very classification process of him/herself under a certain collective identity is one and the same process with the classification of the others under an antipode category. Adorno states, "The formation of stereotypes . . . promotes collective narcissism. Those qualities with which one identifies oneself, the essence of one's own group, imperceptibly become the good itself and the foreign group, the others, bad." 17 An Islamist, for instance, needs the existence of the "other" as the "infidel," in order for his or her image of the Islamist brothers and sisters to make any sense. Meanwhile, some contemporary fascists in the West need their own image of "the Muslims"18 in

${ }^{16}$ Horkheimer and Adorno, Dialictic of Enlightenment, 161.

17 Theodor W. Adorno, Critical Models; Interventions and Catchwords, trans. by Henry W. Pickford (New York: Colombia University Press, 1998), 205.

18 "They who were never allowed untroubled ownership of the civil right which should have gained them human dignity are again called "the Jews" without distinction." Ibid., 144. In today's West, almost all those who come from Middle Eastern and North African families are called "the Muslims" without distension. This view is utterly racist because it treats some very different peoples who are entitled to individual identity and freedom of belief as one homogenous race whose members could not hold different beliefs; they could not be a secular for example. 


\section{MASS MENTALITY}

order for their brotherhood and sisterhood to function. It seems that this kind of reductionist attitude applies to fascism in general.

Horkheimer and Adorno write, "With bourgeois property, education and culture spread, driving paranoia into the dark corners of society and the psyche. But as the real emancipation of humanity did not coincide with the enlightenment of the mind, education itself became sick." 19 Paranoia is the central theme in a culture, and the established group is paranoid about the outside world because its members project their madness in the world. The world represents a constant conspiracy to the group. ${ }^{20}$ Mass culture provides the members of the group with patterns of stereotypes that are formed around the paranoiac stance which is the group's main stance toward the outside world. ${ }^{21}$ Eventually, "stereotypes replace intellectual categories."22 Intellectually, considering every "individual" as a distinct subject with individuality is too demanding for a paranoid mind in the age of mass production. Thinking becomes "an old-fashioned luxury" and "Everyone is labeled as a friend or a foe. The disregard for the subject makes things easy for the administration." 23 Culture is the screen which provides a pre-digested picture of the world to the members of the established group, and its dynamo is paranoia. It is the commodity through which the group perceives the world, so it minimizes the chore of thinking for the submitted members of the group; it turns subjects to paranoiac reductionist people. In the era of mass production, this paranoiac reductionism, which is inherent in the mass culture, is the main characteristic of the mass mentality that seems to be normal only because it is the mentality of the majority. Therefore, a world dominated by mass culture is necessarily a fascist world.

Mass mentality in our era is attracted to the superficial, simple, entertaining, and uncomplicated: in one word, to the stupid. The culture industry produces what is stupid because the stupid is the consumable. I intend to use the term "stupidity" as a descriptive term rather than as a judgmental one. Stupidity is a characteristic of popular culture. Adorno, describing popular listening and popular music, says, "regressive, too, is the role which contemporary mass music plays in the psychological household of its victims. They are not merely turned away from more important music, but they are confirmed in their neurotic stupidity, quite irrespective of how their musical capacities are related to the specific musical culture of earlier social phases." $24 \mathrm{He}$ adds, "There is actually a neurotic mechanism of stupidity in listening, too; the arrogantly ignorant rejection of everything unfamiliar is its sure sign. Regressive listeners behave like children. Again and again and with stubborn malice, they demand the one dish they have once been served." 25

\footnotetext{
${ }^{19}$ Ibid., 163

20 Ibid.

${ }^{21}$ Ibid., 163-166.

22 Ibid., 166.

${ }^{23}$ Ibid., 167.

24 Adorno, Culture Industry, 47.

25 Ibid., 51.
} 
What Adorno speaks of is the antagonism between culture and individualism. Every individual case represents something new, different, unfamiliar, a reference to "the other," and, thus, a threat to mass mentality. Therefore, mass mentality through its practice of culture does not hesitate to use its fascist power to eliminate any individualist case. "The repetitiveness, the selfsameness, and the ubiquity of modern mass culture tend to make for automatized reactions and to weaken the forces of individual resistance." 26

Mass mentality is addicted to routine. Routine anesthetizes the mind, which is precisely what a mass individual seeks. Repetition of simple patterns is the ideal method of creating routine. That is why the fundamental rule of popular music is repetition. Never has repetition been as easy as it is in the age of mechanical reproduction. ${ }^{27}$ Therefore, our age is the golden age for mass mentality and its manifestation in mass culture. In "On Popular Music," Adorno says "standardization" is the hallmark of popular music as opposed to non-standardization with respect to serious music. Basically, in popular music the parts are replicable, predictable, and automatically structured. ${ }^{28}$ Popular music is pre-digested for its listeners through the process of standardization. ${ }^{29}$ Mass mentality is addicted to stupidity; that is why it cannot critically adopt works of art that require serious intellectual participation from the individual recipient. Consumption rules the production of popular art. Art within the frame of popular culture is mere entertainment, and as such it has to require as little thinking as possible. Adorno says, "the pre-digested quality of the product prevails, justifies itself and establishes itself all the more firmly in so far as it constantly refers to those who cannot digest anything not already predigested. It is baby-food: permanent self-reflection based upon the infantile compulsion towards the repetition of needs which it creates in the first place." 30 A pre-digested production is a production, or what is mistakenly called work of art, that requires the minimum amount of thinking from the recipient. In fact, popular music kills thought, unlike serious music which through centuries has stimulated contemplation and thoughtful reflection. It is true that popular culture is not completely a product of the masses, but mass mentality is too idle to digest any culture higher than popular culture. Adorno, however, thought the distinction between popular art and high art is created by advanced capitalism. Adorno's concern is the relation between art and human consciousness. He thinks that, in the age of advanced capitalism, neither high culture nor popular culture conveys a motivation of resistance and expanding

\footnotetext{
${ }^{26}$ Ibid., 160.

${ }^{27}$ Ibid., 67.

28 Theodor Adorno, "On Popular Music," in Journal on Popular Culture, Vol. 2 $<$ http://www.icce.rug.nl/ soundscapes/DATABASES/SWA/On_popular_music 1.shtml $>$, March 17, 2008.

${ }^{29}$ Ibid., 23.

30 Adorno, Culture Industry, 67.
} 


\section{MASS MENTALITY}

human freedom..$^{31}$ Nevertheless, it seems that after the Second World War, he supported the idea of "autonomous art." 32

Culture industry does not have a certain criteria for art; instead, it commodifies whatever that can be profitable, i.e. popular. The essential suppliers of culture industry are the popular groups who supposedly and allegedly rebel from the conventional. Those groups, who also seek popular attention and thus submit to the standards of popular mentality, save culture industry from death because they perpetually provide it with new sealable commodities. Common dissatisfactions that are expressed in forms of fashionable middle-class intellectual complaints are mistakenly thought to be a counter force of culture industry and they are considered as a harvest of "freedom". In reality, this manipulated freedom is a part of the dialectic of culture industry. Culture industry does not represent a static case of control; rather, it is a dynamic process of creativity and hegemony which functions dialectically. Culture industry would die off if it created a set of cultural items that would control the so-called main stream mentality for a long term. Like material industry, cultural industry constantly discredits its own products in order to be able to market its "newer" products. The very strategy of advertising depends on attacking the "common" as the "outdated". Culture industry crucially needs the social groups who reject a fashion through creating another potential fashion. It does not fight people's ideas; rather it adopts them and turns them to domestic elements of culture. Culture industry gives people what people want to take and it invests people's boredom, anger, and rebelliousness. Popular mentality is the crucial condition that makes culture industry possible in the first place. It is not just acceptable to rebel against what is presently considered mainstream, but it is also very beneficial for the very system of culture industry. As long as some groups are attracted to "outside-ness", the raw material of the culture industry is guaranteed. Besides, some groups will always be attracted to "outside-ness" because boredom is built-in to culture.

The relation between the system of culture industry and popular mentality has not only been simplified to dominant and dominated relation, but it also relies on simplification. The popular mentality is not interested in serious philosophical analyses of the world; rather, it is interested in one dimensional beliefs. A philosopher, with serious intellectual activities, would not become a popular icon as much as a rock star with a bunch of simply stated slogans becomes a popular icon. Even a philosopher such as Marx or Nietzsche did not become popular until they were tragically simplified. Culture industry is not another kind of industry, but it is a part of the industry. Hence, it has the ability to adopt every idea that can become popular. Therefore, it necessarily responds to popular mentality.

31 Theodor W. Adorno, "Art, Autonomy and Mass Culture," in Art in Modern Culture:An Anthology of Critical Texts, ed. by Francis Frascina and Jonathan Harris (New York: Icon Editions, 1992), 75.

32 Francis Frascina and Jonathan Harris, eds., Art in Modern Culture: An Anthology of Critical Texts, 38. 
Mass media produce multilayered works in order to target the greatest number of recipients. This is the idea of advertisement, and most products of mass media are advertisements because the recipient in the system of culture industry is nothing but a potential consumer. Since mass media draw as large an audience as possible, they create works that can be exciting for the less cultivated audiences and, at the same time, provocative for the more cultivated recipients. For example, films such as The Sixth Sense (1999) and The Matrix (1999) have drawn audiences from a variety of intellectual backgrounds. They can speak to different sensational stimulations and intellectual speculations. ${ }^{33}$ Therefore, Adorno's adjective, "multilayered," is an appropriate description of mass media. Regardless of the nature of the works produced by mass media, the masses do not appreciate them for aesthetic reasons. Some works of art can capture the attention of millions and this sounds strange to those who take the distinction between low art and high art seriously. I think it is in the nature of some works of art to be able to speak to unsophisticated audience as well as to a critical recipient because they produce multiple discourses and receiving of each takes a different intellectual apparatus. However, for Adorno the important question is how art, both popular and serious, is manipulated within the system of the culture industry. "Art" in the system of the culture industry is not an attempt to recreate the world; rather it too is run by the principle of maximizing profit. It is an amazement that rehabilitates the labor force and, at the same time, the product that has an exchange value which advertises for itself and other products and practices as well. Popular culture is the force of unification that has its tremendous effects on sustaining the forces of production under the capitalist relations of production. ${ }^{34}$

A novel that wins the Nobel Prize for Literature because of its artistic significance would later become popular because of the prize it won. Hermann Hesse's novels are interesting to readers who look only for entertainment and simple "wisdom," but they are also philosophically provocative. Adorno thinks the division between high art and popular art is maintained by the culture industry. ${ }^{35}$ The culture industry has drastically changed the sociology of art and intelligentsia. The traditional cultured elites have disappeared, and the masses who were formerly excluded from the regular audiences of art are now the "consumers" of popular culture. ${ }^{36}$ The popular becomes more popular regardless of artistic value. The mass individual follows what is popular in order to feel updated. In the age of mass culture, it is important not to have a distinct character; what matters is to stay with the popular. A mass individual's

33 Adorno has a unique theory on cinema explained best in "Transparences on Film" (178-186). For him, film is a very controversial case of "art" because of the too realistic relation between film and its objects, it is difficult for film to become art. Also, for the same reason, film produces collective behaviors among mass audiences. Adorno always considers film, along with popular music, as the heart of mass culture.

${ }^{34}$ J. M. Berstein Introduction to The Culture Industry: Selected Essays on Mass Culture (London: Routledge, 2001), 7.

35 Adorno, Culture Industry, 159.

${ }^{36}$ Ibid., 161. 


\section{MASS MENTALITY}

taste is miserably dependent. That fact is known very well by the market runners. Once they succeed at popularizing some product (sometimes by faking popularity), the product's popularity becomes the strongest means of gaining more popularity until it is sold to millions of masses who are exposed to its advertisements. A mass individual lacks aesthetical judgment; he or she instead has a predilection for whatever is popular. "The best-seller book" invites those who lack a sense of judgment, those whose measurement belong to the masses, but the masses are in the same position of passivity. Therefore, even when an artistic work, such as Beethoven's ninth symphony, becomes popular, it does not become popular for the artistic value it possesses. Everything is already evaluated, ranked, and valued, for the mass individual. A mass individual's passive affinity with the popular provides a golden opportunity for culture industry to work hand in hand with capitalism. Walter Benjamin saw in the democratization of art an element of proletarian revolution, and he was optimistic about the mass influence of cinema. ${ }^{37}$ In the decay of the aural distance between the work of art and the people Benjamin saw a progressive potentiality, as did Brecht who famously tried to eliminate the distance between art and the audience. Adorno repeatedly decried what he considered to be a bad influence of the Brechtian Marxism on Benjamin. ${ }^{38}$ Instead of a promise of revolution, Adorno saw signs of a huge manipulation in the system of popular culture and a decline of resistance that he thought is maintained in serious art. ${ }^{39}$ The totalitarian and the manipulative nature of popular culture threaten individualism and freedom of choice because popular culture overshadows art and when it adopts a work of art, it will only commercialize it. This epoch is full of performance but it lacks recipients. Mass media intend to damage individuality because they constantly put forward popular dreams in the form of individuality. What happens is that creating "individuality" becomes the task of the culture industry, and that is necessarily an anti-individualist form of individuality because its traits depend on the descriptions set up by popular mentality and it is directed to the same mentality, which is highly collective.

In a radio debate between Adorno and Canetti, Adorno asks Canetti about the role of masses in fascism and National Socialism. In response, Canetti says, "... . dictatorships we have experienced are made up entirely of crowds . . . without the growth of crowds, which is especially important, and without the deliberate artificial excitation of ever larger crowds, the power of dictatorships would be completely unthinkable." 40 Canetti also claims that the "crowd symbols" with which certain crowds relate easily are a major motivation for crowds to act because of the effect those symbols have on the

\footnotetext{
37 Walter Benjamin, "The Work of Art in the Age of Mechanical Reproduction of Art," in Illuminations; Essays and Reflections, ed. by Hannah Arendt (New York: Harcourt, Brace and World Inc., 1968), 234.

${ }^{38}$ For example see, Theodor W. Adorno et al., Aesthetics and Politics, trans. and ed. Rodney Taylor (London: Verso, 2007), 126. Also see Adorno, Culture Industry, 182.

${ }^{39}$ Ibid., 121.

${ }^{40}$ Elias Canetti, "Discussion with Theodor W. Adorno," in Thesis Eleven 45 (1996), 5.
} 
individual. 41 Both Canetti and Adorno emphasize that the major force that makes fascism and totalitarianism possible is the masses as a physical presence of actual human beings. ${ }^{42}$

The Frankfurt School realized that capitalism could control the threatening spots within the body of its social and economic system. The Frankfurt School pointed to the manipulative capabilities of capitalism through which capitalism could discharge real possibilities of mass revolutions. Adorno focused on the subtle hegemonic apparatus of the culture industry as a main tool in the hands of capitalism to disaffect possibilities of revolution by controlling the vast majority of people. ${ }^{43}$ Culture industry is capitalism's contemporary method for a complete commoditization of culture. The commoditization of culture results in conformity, as opposed to critical thinking. Mass culture is the realm where mass individuals come together under a regime of totems and fetishism. Fascism is a fetishistic celebration of the collective spirit that is embodied in mass culture.

\section{Mass Mentality, Fascism, Culture Industry}

Mass culture cannot live without the image of an enemy. If there is no enemy, mass culture creates one. Fighting the "internal enemies" never satisfies mass culture's fascist need for enmity, so it looks for enemies and their images outside in order to feel a real threat. Mass culture is paranoiac by virtue of its collective submission to an irrational perspective of the world. What forms the core of the fascist unity in mass culture is the alleged threat from the outside world. This image of the other, the different, as the enemy is what sustains mass culture. Mass culture depicts the minorities as sleeping threats who have suspicious loyalties. The mentality that demonized the Jews in Nazi Germany is the same mentality that demonizes certain ethnic and cultural minorities in today's West. It is easy now for the mass media to point at the Nazi Devil and speak of the injustice that was done to the Jews, but at the same time mass culture reproduces other images of imaginary enemies out of defenseless minorities whose members are seen more like timed bombs rather than individual human beings. If a white man shoots at his schoolmates in the US, it is a case of an abnormal individual, but if a non-white commits such crime, everyone in his or her ethnic group is responsible. If numerous members of a minority prove to be excellent citizens, they are assumed to be people who learnt "our way of life," but if one member of the same minority commits a crime, the whole minority is guilty by association.

In capitalist society, there is nothing humane enough to unite the masses, so the reproduction of the image of an enemy is the only force that is powerful enough to make the masses feel like one. For that reason, the fascists on one side of the world serve the fascists on the other side of the world in the

\footnotetext{
${ }^{41}$ Ibid., 4.

42 Ibid., 5.

43 For more on this discussion see the second chapter of: Dominic Strinati, $A n$ Introduction to Theories of Popular Culture (New York: Routledge, 2004).
} 


\section{MASS MENTALITY}

best possible way: each side embodies the perfect enemy to the other. How else the minorities can be accused of dangerous external loyalty? For the mass mentality, a member of $\mathrm{x}$-minority is already unable to be anything but an $\mathrm{x}$, so to create the image of internal enemies all what is needed is to find an ethnic or a cultural link between the minority and the external enemy. Once Japan entered the Second World War, the American and Canadian citizens who happened to have Japanese ancestors were viewed as nothing but an extension of the enemy. A citizen whose last name happened to be Mohammad, is counted as a Muslim regardless of his or her religion, and as a Muslim he or she is seen as a potential Islamist/terrorist regardless of his or her individuality, basically because he or she has been deprived of individuality. A white person's identity is driven from his or her personal discourse; whereas, a nonwhite person's identity is fixed because he or she is not seen as somebody who could have a personal discourse. An Asian is nothing but an Asian. A Mohammad is nothing but a Muslim. A black person is a black and nothing besides. Minority members are projects for potential images of potential enemies. There is nothing that can hold together the society that has been torn apart by antagonistic conflicts of capitalism but the hate of an enemy. Minorities are the stimuli of the fascist passion. Fascism of the majority desperately needs minorities to prove the constancy of a threat.

The first piece of "information" that the president of the Virginia Tech University gave to the media following the shooting at the university on April 17, 2007 was about the race of the shooter: "an Asian." The message was "the bad guy is from somewhere else; he is not one of us." If the shooter, who actually grew up in America, had won a Nobel Prize, he would have been referred to as an American. Populist Western fascism multiplied the image of fascist Islamism because without such an image it would die off. Fascist forces provide each other with excuses for more violence and to persuade more people to join them. The soldier does not provoke the image of "a murderer" in mass mentality. Instead, it is a poetic word. A "soldier" is someone who dies for "us" in a war against "them." Popular culture gives rise to every possible form of fascism because it takes root in the myth of collective identity, of the identity that enables the weakest person to say "us," and take pride from that, which is the psychological escaping gate from banality. At the same time, every minority member is easily stereotyped, which is just the first step towards dehumanizing and then demonizing him or her. The stereotyped is thrown out of the area of individual consideration, and the stereotyping mind is addicted to the typical fascist stupidity. Stereotyping, as an intellectual disorder, is the substitute for the chore of thinking for the minds that minimize the act of thinking. The fascist definition of "us" is one and the same process of the classifying and stereotyping the other. Only through the exclusion of the other can a notion of a collective identity be constructed. Hence, mass culture is fascist from the moment of its formation.

In "Freudian Theory and the Pattern of Fascist Propaganda," Adorno studies the relationship between the bonds that turns "individuals" to masses. He credits Freud's study of mass psychology for predicting fascism in the 
twentieth century. "According to Freud, the problem of mass psychology is closely related to the new type of psychological affliction so characteristic of the era which for socio-economic reasons witnesses the decline of the individual and his subsequent weakness." 44 According to Adorno, Le Bon's contribution is also crucial in the realization of "psychology of masses," though Freud was the first psychologist who did not disgust the masses and instead he wondered what turned groups of individuals into masses. Adorno writes, "he [Freud] tries to find out which psychological forces result in the transformation of individuals into a mass. 'If the individuals in the group are combined into a unity, there must surely be something to unite them, and this bond might be precisely the thing that is characteristic of a group.' This quest, however, is tantamount to an exposition of the fundamental issue of fascist manipulation." 45

For Freud, Adorno explains, what happens to individuals when they form masses can be explained in terms of libidinal phenomena. Individuals lose their rationality when they join masses. ${ }^{46}$ Adorno tries to connect that with fascism as a "rebellion borrows its energies partly from other psychological agencies which are pressed into the service of the unconscious." 47 Adorno then searches for the mechanisms that change sexual energy to feelings on which masses are constructed internally. ${ }^{48} \mathrm{He}$ says Freud noticed how "love" in organized groups is masked by religious images and rituals. ${ }^{49}$ Fascism needs to turn "love" to authoritarian fetishism and that is exactly what shapes the pattern of fascism. ${ }^{50}$ Freud explains the relation between a leader and the followers (masses) in terms of a father-children relation. The children feel the need for total obedience to the father, who is the representative of the super ego. The herd feels the need to submit to an absolute authority. They want to be governed because they cannot bear their freedom..$^{51}$ Fascist propaganda, Adorno explains, relives the primal image of "the father" which stimulates the psychological thirst for obedience. That is why fascist media concentrate on the "greatness" of the leader rather than the problems in reality and possible objective corresponding politics. ${ }^{52}$ In Saddam Hussein's Iraq, the media did little else besides extol the "wisdom of the father-leader," to use one of their own expressions. Even after Saddam Hussein was executed, some Iraqis claimed that to have seen his image on the face of the moon, which for them is a sign of divinity. "Idealization," according to Freud, is the process according to which sexual energy is transformed to a fascist bond among the members of the herd and between themselves and their leader. ${ }^{53}$

\footnotetext{
${ }^{44}$ Adorno, Culture Industry, 134.

45 Ibid., 135.

46 Ibid., 136

${ }^{47}$ Ibid., 137.

48 Ibid.

${ }^{49}$ Ibid.

50 Ibid., 138.

51 Ibid.

52 Ibid., 138-139.

53 Ibid., 139
} 


\section{MASS MENTALITY}

Adorno identifies the distinctive characteristics of a fascist leader. For example, the leader does not need love because he is over and above such emotional needs; however, the people are automatically supposed to love the leader. ${ }^{54}$ The leader appears as the over-man; at the same time, he or she appears to be one of them. I think this is not a contradiction. The leader's appearance as an average person is nothing but "modesty," though a false one. The leader seeks this "modesty" only as a condition of perfection. That is to say the leader's image is a combination of perfect traits, one of which is "modesty." Again, Saddam Hussein used to be seen on TV going to workingclass Iraqi homes to eat, drink, and chat with them. However, the Iraqi people had to see these "normal" behaviors of their leader wherever they turned from TV shows to newspapers and wall portraits.

Fascist groups, such as armies, are societies with their own internal rituals and hierarchies. The image of the leader always stands at the top, representing the general principle of idealization. ${ }^{55}$ The hierarchical order guarantees the exercise of sado-masochistic tendencies of the fascists within their system. The principle is, in Hitler's words, "responsibility towards above, authority towards below." 56 The most terrible exercise of power is committed against the dominated minorities. For Freud, Adorno explains, "the dichotomy between in- and out-groups is of so deep-rooted a nature that it affects even those groups whose 'ideas' apparently exclude such reactions." ${ }^{77}$ Freud thinks even the groups whose ideal is "love," have the same classification of "us," who believe in the religion of love, and "they," who do not believe in the religion of love. The groups that claim "love" as their fundamental principle generate hatred against the out-groups. ${ }^{58}$ Those who do not believe in the principle of love eventually are hated because they are not good enough to believe in love. Collective identity in all its forms such as religion and culture generate enmity towards the outside world.

Another characteristic of fascist discourse is the undermining of individual differences within the fascist group, and the emphasizing of the differences between the in-group and the out-group, often by accusing the latter for all kinds of conspiracy. ${ }^{59}$ In this sense, every fascist group needs the existence of other antagonistic fascist groups in order to justify its own fascist discourse to the members of its group. Even when there is no identifiable enemy, the whole outside world is a project for the creation of an "enemy" through propaganda.

Islamist fascism and a corresponding fascist block in the West simply feed each other. For bad things that happen in the world, Islamist fascism, on the one hand, simply points at the US and Israel. The right wing forces and fascists in the West, on the other hand, point at the Islamic enemy to justify

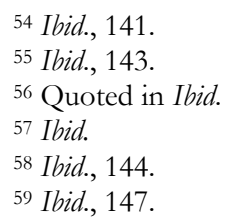


their fascist agenda. Not strangely, the conflicting fascist groups seem very similar regarding their religious, moralist, and discriminatory discourses.

The more threatened the members of the group feel by the outside world, the more they repress their individuality and transform their relationships to fascist brotherhood. This brotherhood is built on repression, not equality. ${ }^{60}$ People who have been damaged by the hideous circle of labor and consumption long for meaning in their collective projects, and this longing relies on excluding and demonizing the outside: the different. The direct product of this unity of sick individuals, who are too weak to live as independent individuals and see others as independent free individuals, is fascism. Fascism is therefore a normative element of culture.

Department of Philosophy, Brock University, Canada

\section{References}

Adorno, Theodor W., "Art, Autonomy and Mass Culture," in Art in Modern Culture: An Anthology of Critical Texts, ed. by Francis Frascina and Jonathan Harris (New York: Icon Editions, 1992), 74-79.

, Critical Models; Interventions and Catchwords, trans. by Henry W. Pickford (New York: Colombia University Press, 1998). , "On Popular Music," in Journal on Popular Culture, Vol. 2 < http://www.icce.rug.nl/ soundscapes/DATABASES/SWA/On p opular music 1.shtml>, March 17, 2008.

The Culture Industry: Selected Essays on Mass Culture (London: Routledge, 2001).

Adorno, Theodor W. et al., The Authoritarian Personality (New York: Harper \& Row Publications, 1950).

Adorno, Theodor W. et al., Aesthetics and Politics, trans. by Rodney Taylor. (London: Verso, 2007).

Benjamin, Walter, "The Work of Art in the Age of Mechanical Reproduction of Art," in Illuminations; Essays and Reflections, ed. by Hannah Arendt (New York: Harcourt, Brace and World Inc., 1968).

Berstein, J. M., Introduction to The Culture Industry: Selected Essays on Mass Culture (London: Routledge, 2001), 1-28.

Canetti, Elias, "Discussion with Theodor W. Adorno," in Thesis Eleven, 45 (1996), 1-15.

Deleuze, Gilles and Felix Guattari, A Thousand Plateaus; Capitalism and Schizophrenia, trans. by Brian Massumi (Minneapolis: University of Minnesota Press, 1987).

Foucault, Michel, "The Body of Condemned," in Foucault Reader, ed. by Paul Rabinow (New York: Pantheon Books, 1984).

Frascina, Francis and Jonathan Harris eds., Art in Modern Culture: An Anthology of Critical Texts (New York: Icon Editions, 1992).

${ }^{60}$ Ibid., 146. 


\section{MASS MENTALITY}

Horkheimer, Max, and Theodor Adorno, Dialectic of Enlightenment: Philosophical Fragments, trans. by Edmund Jephcott (Stanford, California: Stanford University Press, 2002).

Strinati, Dominic, An Introduction to Theories of Popular Culture (New York: Routledge, 2004). 